\title{
Using Kid Power to Teach Kids about Mental Retardation: A Long-Term Follow-Up
}

\author{
Amy Turnbull \\ Fifth Grade, Hillcrest Elementary School \\ Lawrence, Kansas \\ G. J. Buzz Bronicki \\ The University of Kansas
}

This study is a follow-up of my 1985 school science project (Turnbull \& Bronicki, 1986) that I did in the fourth grade. In my 1985 study, I gave an attitude test to kids in two second grade classrooms. Then I taught a 50 -min lesson about mental retardation to one of the classes. I gave the attitude test to both classrooms again. The kids in the experimental group that I taught had a positive change in their attitudes toward people who, like my brother Jay, have mental retardation. The attitudes of the kids in the control group did not change.

I did not report a statis tic in the 1986 article that is very important in checking the hypotheses in this study. The positive gains in attitudes for the experimental group were significantly greater than those of the control group, $t(24)=2.106, p<.05$.

This year I was interested in what these kids' attitudes would be after 1 year. Would they keep their positive attitudes? The important thing is for kids to develop a habit of positive attitudes that stays with them. This means that you have to go back and check to find out what is going on with their attitudes.

My other question was if other kids could be effective teachers. This is important, because there are lots of classes that need to be taught in my school and in other places in this country. I wondered if the successful attitude change I got last year could happen when other kids teach. I think the only thing different about my teaching is that I have a brother with mental retardation. I wondered if kids without a family member with mental retardation could get the same effect. The purpose of my study was to test three hypotheses:

Hypothesis 1: Positive changes in attitudes toward

Amy Turnbull would like to give special thanks to Danika Baker and Katie Schwartzburg for helping her by teaching one of the third grade classes. Ather request, the second author served as statistical and design consultant. All other aspects of this science project were performed by the first author.

Requests for reprints should be sent to Amy Turnbull, 6301 Wynkoop Blvd., Bethesda, MD 20817. people with mental retardation will remain the same over a period of time.

Hypothesis 2: Teaching kids about mental retardation will improve their attitudes toward people with mental retardation.

Hypothesis 3: Any kid with a positive attitude and with a good understanding of mental retardation can teach other kids.

\section{Method}

This year the same kids $(n=19)$ and some who were new to my school $(n=2)$, now in the third grade, helped me in my science report. Again, I gave a pretest for attitudes (Rude, 1982) to the two third grade classes. Then I taught one class myself, and I taught my friends Katie Schwartzburg and Danika Baker to teach the other class. Katie and Danika scored the highest on the posttest last year. They are also my neighbors and are around my brother a lot. They have very positive attitudes and a good understanding of mental retardation.

We both taught the same lesson but to different classes. As last year, the lesson was about $50 \mathrm{~min}$ long. In our lessons we explained the meaning of mental retardation by using a record player and a record. We told the kids that record players can play music on the slow speed and on the fast speed. Then we played "We Are the World" on both speeds to demonstrate what we meant. We said brains are like record players-some kids learn on a slow speed and others learn on the fast speed, but all can learn and have a happy life. After this we showed a videotape of the Kansas University basketball team working with Special Olympics athletes. I amvery proud that Coach Larry Brown and the KU players like people with mental retardation. Then we read a book about a boy with mental retardation and had a discussion. The last thing I did was give a posttest for attitudes to both classes.

\section{Results}

I used different statistical tes ts (Bruning \& Kintz, 1968) to check my hypotheses. 
Hypothesis 1. I compared the posttest scores from 1985 with the pretest scores from 1986 for last year's experimental group. I got a score of Wilcoxon $\mathrm{T}=22$ (number of kids in the group was 10). The Wilcoxon $\mathrm{T}$ needed for a real difference is 8 or less. The test shows that the kids' attitudes did not appear to change. They remained positive for 1 year.

For last year's control group I got a Wilcoxon $\mathrm{T}=$ 18 (number of kids in this group was 9). Wilcoxon $\mathrm{T}$ needed for a real difference is 6 or less. The test shows that the kids' attitudes probably did not change in 1 year. They appeared to remain the same--they did not get better or worse.

Using a Mann-Whitney $U$ test, I compared the 1986 pretest scores for both groups. The attitude scores for last year's experimental group $(n=10)$ were significantly more positive than the attitude scores of last year's control group $(n=9), U=8.5, p<.05$.

All the tests put together appear to support my first hypothesis. The kids' attitudes did not change in the year since my first study.

Hypothesis 2. I compared the pretest and posttest scores of the kids that were in last year's control group $(n=9)$ that took part in this study. They had a significant positive improvement in attitude (Wilcoxon $\mathrm{T}=3$, $\mathrm{p}<.05)$. I then compared the pretest and posttest scores of all the kids in both third grade classes. I got a score of Wilcoxon $\mathrm{T}=53.5$ (number of kids in both classrooms was 21). The Wilcoxon $\mathrm{T}$ needed for a real difference is 59 or less. This is a real difference. The kids' attitudes improved after the lessons that Danika and Katie taught and the lesson I taught.

Hypothesis 3. Again using the Mann-Whitney $U$ test, I looked at the scores on the posttests of the kids in the class that I taught and the scores of the kids in the class that Danika and Katie taught. I got a score of $U=.37$. The $U$ must be 30 or less to be a real difference.

So, the class Katie and Danika taught did just as well as the class that I taught. This is pretty good proof that kids with a positive attitude and a good understanding about mental retardation can teach other kids.

\section{Discussion}

The kids I taught last year when they were in the second grade kept their positive attitudes for 1 year. I think there are two reasons. First, I talked to them "from one kid to another by using words they understood. I think kids are the best teachers on a topic like mental retardation. Second, maybe the kids looked up to me because I'm several years older so they care what I think. Older kids can help younger kids to have a more positive attitude.

Katie and Danika did a great job of teaching. The kids they taught did just as well as the kids I taught. When choosing teachers, I think it's a good idea to go with kids who have positive attitudes and a good understanding of mental retardation. Katie and Danika had been in the class that I taught last year, but the main reason I think they have positive attitudes is that they are around my brother a lot. I think kids with personal experience will make the best teachers. The place to start Kid Power is with brothers and sisters of people with mental retardation and their friends. These people can speak from their minds and from their hearts.

The part of my lesson this year that I liked most was the videotape of the Kansas University basketball team working with Special Olympics athletes. Coach Larry Brown is very famous. All kids look up to him and the KU players. The kids really got into mental retardation when they realized that Coach Brown and the players like people with mental retardation. The kids may have been thinking something like, "I want to be on the KU basketball team, so I'm probably going to be nice to people with mental retardation. If I make the team, we might work with Special Olympics, have fun helping people, and make some new friends." I wish every basketball team in the whole country would do what Coach Brown and the KU players do with Special Olympics. The tape showed more than just basketball. It showed fun, laughter, excitement, pats on the back, cheering, and high fives. It also had background music that stays with people. The music was "There's a Place for Us" from West Side Story. The tape makes kids feel "up" and happy about being with people with mental retardation. It makes them keep singing "There's a Place for Us."

In summary, I think Kid Power makes a difference in creating positive attitudes. Kids listen to kids and to people they respect like basketball coaches and players. When you put it all together, good things can happen for everyone.

\section{References}

Bruning, J. L., \& Kintz, P. L. (1968). Computational handbook of statistics. Glenview, IL: Scott, Foresman.

Rude, H. A. (1982). The student attitude and perspective scale. Greeley, CO: University of Northem Colorado.

Turnbull, A., \& Bronicki, G. J. (1986). Changing second graders' attitudes toward people with mental retardation: Using kid power.Mental Retardation, 24(1), 44-45.

Received: November 10, 1986

Final Acceptance: February 6, 1987 